\title{
Culture-independent analysis of endophytic bacterial communities associated with Brazilian sugarcane
}

\author{
G.S. Magnani ${ }^{1}$, L.M. Cruz ${ }^{1}$, H. Weber ${ }^{2}$, J.C. Bespalhok ${ }^{2}$, E. Daros ${ }^{2}$, \\ V. Baura ${ }^{1}$, M.G. Yates ${ }^{1}$, R.A. Monteiro ${ }^{1}$, H. Faoro ${ }^{1}$, F.O. Pedrosa ${ }^{1}$ \\ and E.M. Souza ${ }^{1}$ \\ ${ }^{1}$ Departamento de Bioquímica e Biologia Molecular, \\ Universidade Federal do Paraná, Curitiba, PR, Brasil \\ ${ }^{2}$ Departamento of Fitotecnia, Universidade Federal do Paraná, \\ Curitiba, PR, Brasil \\ Corresponding author: E.M. Souza \\ E-mail: souzaem@ufpr.br
}

Genet. Mol. Res. 12 (4): 4549-4558 (2013)

Received September 26, 2012

Accepted August 1, 2013

Published October 15, 2013

DOI http://dx.doi.org/10.4238/2013.October. 15.3

\begin{abstract}
Sugarcane is an economically important culture in Brazil. Endophytic bacteria live inside plants, and can provide many benefits to the plant host. We analyzed the bacterial diversity of sugarcane cultivar RB-72454 by cultivation-independent techniques. Total DNA from sugarcane stems from a commercial plantation located in Paraná State was extracted. Partial 16S rRNA genes were amplified and sequenced for library construction. Of 152 sequences obtained, 52\% were similar to $16 \mathrm{~S}$ rRNA from Pseudomonas sp, and $35.5 \%$ to Enterobacter sp. The genera Pantoea, Serratia, Citrobacter, and Klebsiella were also represented. The endophytic communities in these sugarcane samples were dominated by
\end{abstract}


the families Enterobacteriaceae and Pseudomonadaceae (class Gammaproteobacteria).

Key words: Endophytic bacteria; Microbial diversity; Sugarcane; 16S rRNA

\section{INTRODUCTION}

Endophytic bacteria live inside plants without causing damage to their hosts (Hallmann et al., 1997), and actually, these bacteria can contribute to plant growth (Rosenblueth and Martinez-Romero, 2006). This type of bacteria has been found in a broad range of agricultural plants, including rice, sugarcane, sorghum, soybean, rape seed, and sweet potatoes (Cavalcante and Döbereiner, 1988; Germida et al., 1998; Kuklinsky-Sobral et al., 2004; Sun et al., 2008; Terakado-Tonooka et al., 2008; Rout and Chrzanowski, 2009). These microorganisms are being increasingly used in agricultural practices for enhancing crop productivity and reducing the costs of pesticides and fertilizers (Perrig et al., 2007). Among the benefits conferred to the plants by endophyte inoculation are an increase in plant resistance to diseases, an increase in phosphate availability, and supply of fixed nitrogen (Araujo et al., 2002; Oliveira et al., 2002; Kuklinsky-Sobral et al., 2004). Therefore, there is great interest in the identification and characterization of endophytes, by studying the dynamics of plant bacterial populations and ecological interactions.

Before the last decade, the majority of studies on endophytic bacteria used cultivationdependent methods. The growth conditions select fast-growing organisms, which are well adapted to the culture conditions. In contrast, cultivation-independent methods allow assessment of a larger portion of the plant microbiota (Tian et al., 2007).

Sugarcane (Saccharum spp) is one of the most important crops in Brazil, which amounts to a quarter of the world's production. Recently, interest in sugarcane has increased since it is the most promising sustainable source of biofuel. Alternatives for improving crop production for this Poaceae and reducing carbon dioxide emissions are under intense investigation. Most of the studies of endophytic bacteria have focused on the isolation of diazotrophic endophytes, and the organisms frequently found are Gluconacetobacter diazotrophicus, Herbaspirillum spp and Azospirillum amazonense (Baldani et al., 1986; Reis Junior et al., 2000).

Cultivation-dependent methods in $\mathrm{N}$-free media are mainly used in these studies, suggesting that many sugarcane endophytes have not been identified, including bacteria of potential biotechnological use. In agreement with this suggestion, Fischer et al. (2011) recently showed the presence of the genera Ideonella and Herbaspirillum, as well as rhizobial nifH transcripts, in sugarcane.

The organisms cited above (Baldani et al., 1986; Reis Junior et al., 2000; Fischer et al., 2011) were found in stems. Although this high prevalence of classic diazotrophic bacteria has been described in sugarcane, Magnani et al. (2010) observed a dominance of Gammaproteobacteria, mainly from the families Pseudomonadaceae and Enterobacteriaceae in the stems of this plant.

The aim of the present study was to determine the dominant groups endophytically associated with sugarcane by analyzing the bacterial community in adult sugarcane stems using a culture-independent approach. 


\section{MATERIAL AND METHODS}

Two healthy adult sugarcane plants (RB-72454) were collected from an experimental area of Universidade Federal do Paraná, located in Paranavaí in the northwest region of Paraná State. The plants were kept at $4^{\circ}-10^{\circ} \mathrm{C}$, pooled and processed within $24 \mathrm{~h}$ of collection.

The stems were washed in running water, followed by distilled water. The stems (cut at $15 \mathrm{~cm}$ from the soil) were then immersed in $70 \%$ alcohol, followed by flame sterilization of the surface. The surface of sterile stems was completely removed to avoid carryover of epiphytic bacteria, and the internal tissues of the stem ( $22 \mathrm{~g})$ were crushed with a mortar and pestle in sterile Tris- $\mathrm{HCl}, \mathrm{pH}$ 8. The extracts were used for DNA purification with the Ultra Clean Plant DNA kit (MO BIO Laboratories Inc., USA). The purified DNA was then used to amplify the 16S rRNA gene of endophytes by PCR with the primers 27f (AGAGTTTGATCC TGGCTCAG) and 16S805r (GACTACCAGGGTATCTAATCCTG) (Lane, 1991; Soares-Ramos et al., 2003), which yielded a fragment of $800 \mathrm{bp}$. The polymerase chain reaction (PCR) contained 1X PCR buffer (Invitrogen, USA), $1.5 \mathrm{mM} \mathrm{MgCl}, 200 \mu \mathrm{M}$ of each dNTP, 5 pmol of each primer and $1 \mathrm{U}$ TaqDNA polymerase Platinum (Invitrogen). The PCR conditions were: an initial denaturation step at $94^{\circ} \mathrm{C}$ for $3 \mathrm{~min}, 28$ cycles at $94^{\circ} \mathrm{C}$ for $1 \mathrm{~min}, 62^{\circ} \mathrm{C}$ for $40 \mathrm{~s}$, and $72^{\circ} \mathrm{C}$ for $1 \mathrm{~min}$, and a final extension at $72^{\circ} \mathrm{C}$ for $10 \mathrm{~min}$. The PCR products were cloned in the vector pCR2.1 (Invitrogen) and electrotransformed in the Escherichia coli DH10B. For the sequencing reaction the plasmids containing the 16S rRNA gene were isolated by alkaline lysis and further purified on Sephadex G-50 using the Millipore MultiScreen Assay System. Sequences of partial 16S rRNA genes were obtained by the dideoxy-chain termination method using the DYEnamic ET terminator cycle sequencing kit (GE Healthcare, USA) in a MegaBACE 1000 sequencer (GE Healthcare). The Phred program was used for base calling (Ewing et al., 1998) and the sequence edition was performed by BioEdit (Hall, 1999). BLASTn was used for sequence comparison (Altschul et al., 1997) and the taxonomic assignment was made using the best hit. Rarefaction curves were constructed using DOTUR 1.53 (Schloss and Handelsman, 2005). The operational taxonomic units (OTUs) were defined with a threshold of $3 \%$ dissimilarity $\left(\mathrm{OTU}_{0.03}\right)$. Representative sequences of each OTU and related sequences from the GenBank database were aligned with ClustalW (Thompson et al., 1994) and edited with BioEdit (Hall, 1999) to construct a phylogenetic tree from the Jukes-Cantor calculated distance matrices, using the neighbor-joining method with 1000 bootstrap replicates in the MEGA4 program (Kumar et al., 2008). Clone coverage (C) was calculated by the equation:

$$
C=1-\left(\frac{n_{l}}{N}\right) \times 100
$$

where $n_{1}$ is the number of singletons and $N$ the total number of clones (Pachiadaki et al., 2010). The sequences from the 16S rRNA clone libraries were deposited in GenBank and have the following accession numbers: HM122276 to HM122422 and HM594272 to HM594276.

For enumeration of cultivable endophytic bacteria, extracts of surface-sterilized samples of sugarcane stems were obtained, serially diluted and plated on NFbHPN (Pedrosa and Yates, 1984) and LA media. Colonies were counted after $1-5$ days at $30^{\circ} \mathrm{C}$. 


\section{RESULTS}

Colony counting revealed $7 \times 10^{6}$ and $2 \times 10^{7}$ colony-forming units per gram of fresh sugarcane stem on NFbHPN and LA media, respectively, suggesting a high level of bacterial endophytic population.

PCR amplification using the primers $27 \mathrm{f}$ and $16 \mathrm{~S} 805 \mathrm{r}$ and pooled stems of sugarcane extract as template produced a single band of approximately $800 \mathrm{bp}$. Amplification of the same DNA with primers 27f and 1492r (Lane, 1991) produced a band of approximately 1.5 $\mathrm{kb}$ but also often produced a $2-\mathrm{kb}$ band, which was presumably the result of amplification of the mitochondrial rRNA gene. When the sequences of primers $27 \mathrm{f}$ and $16 \mathrm{~S} 805 \mathrm{r}$ were used to search the RDPII database (Cole et al., 2009), a perfect match of both sequences with 152,954 of $1,002,421$ sequences of the available 16S rRNA sequences of the domain Bacteria was observed, suggesting that this pair of primers can be used to evaluate a broad range of bacterial diversity. We, therefore, decided to use primers $27 \mathrm{f}$ and $16 \mathrm{~S} 805 \mathrm{r}$ to amplify the $16 \mathrm{~S}$ rRNA gene of the microbial population of sugarcane, where the product was cloned into pCR2.1 (Invitrogen) and the inserts sequenced.

A total of 288 clones were sequenced using primer $27 \mathrm{f}$, yielding 152 high-quality partial sequences of the 16S rRNA gene. The sequence length varied from 259 to $805 \mathrm{bp}$. The rarefaction curve (Figure 1) constructed using the partial sequences (138 sequences with an alignment of $320 \mathrm{bp}$ ) was partially saturated at 3 and $5 \%$ divergence.

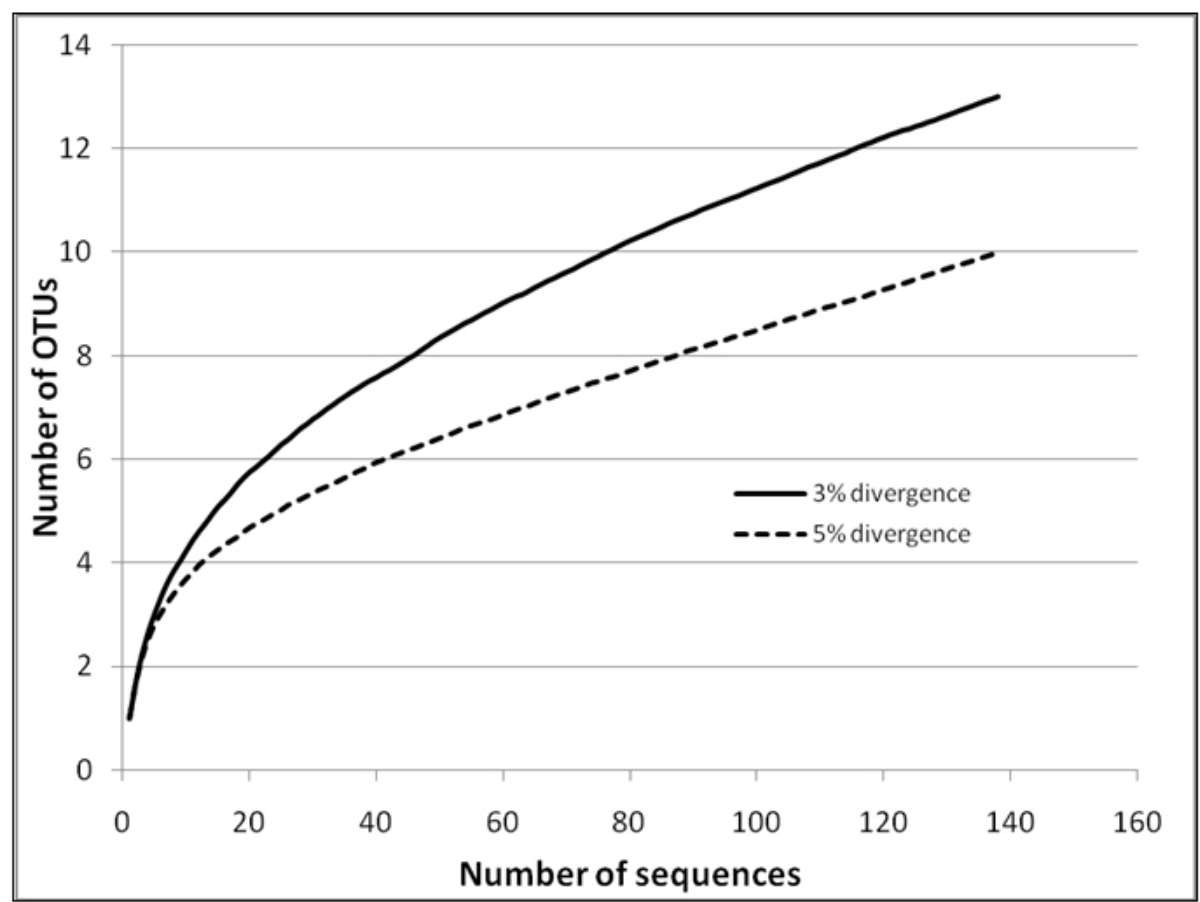

Figure 1. Rarefaction curves from 16S rRNA gene sequences of sugarcane-associated endophytes. Rarefaction curves are shown at taxa levels of species (3\% divergence) and genus (5\% divergence). OTUs = operational taxonomic units. 
To estimate richness, the Chao index was calculated at 3\% divergence and showed 18 OTUs in our sample, a number similar to that shown in the rarefaction curve. The coverage calculation based on 3\% divergence showed that the sequences sampled represented $90 \%$ of the theoretical number of bacterial taxa. These analyses together indicated that the sample was representative of the bacterial endophytic diversity in sugarcane stems.

All sequences obtained had close similarity to 16S rRNA of the Gammaproteobacteria. The two main families found were Pseudomonadaceae (79 sequences) and Enterobacteriaceae (73 sequences) (Table 1). Among the latter family, 50 clones were related to the genus Enterobacter, 17 to Pantoea sp, 4 to Klebsiella, 1 to Citrobacter sp, and 1 to Serratia sp.

Table 1. Distribution of sugarcane endophytes within bacterial taxa according the 16S rRNA gene sequences.

\begin{tabular}{|c|c|c|c|c|}
\hline \multirow[t]{2}{*}{ No. of clones } & \multirow[t]{2}{*}{$\%$ Total clones } & \multicolumn{3}{|c|}{ Best BLAST hit } \\
\hline & & Classification & GenBank accession & $\%$ Identity \\
\hline 1 & 0.7 & Enterobacter $\mathrm{sp}$ & FJ784695 & 97 \\
\hline 3 & 2.0 & Enterobacter $\mathrm{sp}$ & EU653006 & 98 \\
\hline 1 & 0.7 & Enterobacter $\mathrm{sp}$ & FJ870557 & 97 \\
\hline 5 & 3.3 & Enterobacter ludwigii & GQ380575 & 98 \\
\hline 10 & 6.6 & Enterobacter ludwigii & FJ859683 & 99 \\
\hline 3 & 2.0 & Enterobacter cloacae & EF219421 & 99 \\
\hline 2 & 1.3 & Pantoea sp & EU887713 & 99 \\
\hline 5 & 3.3 & Pantoea agglomerans & FJ603033 & 100 \\
\hline 2 & 1.3 & Pantoea agglomerans & EU931561 & 98 \\
\hline 6 & 3.9 & Pantoea dispersa & GQ246183 & 96 \\
\hline 1 & 0.7 & Uncultured Serratia sp & DQ279305 & 100 \\
\hline 57 & 37.5 & Pseudomonas plecoglossicida & GQ301534 & 98 \\
\hline 5 & 3.3 & Pseudomonas putida & DQ482656 & 99 \\
\hline 2 & 1.3 & Pseudomonas sp & EF581816 & 90 \\
\hline 1 & 0.7 & Pseudomonas sp & AB508856 & 94 \\
\hline 6 & 3.9 & Pseudomonas $\mathrm{sp}$ & FJ577973 & 94 \\
\hline 1 & 0.7 & Pseudomonas sp & FJ719329 & 98 \\
\hline 1 & 0.7 & Pseudomonas sp & FN421341 & 99 \\
\hline 1 & 0.7 & Pseudomonas sp & EU580707 & 99 \\
\hline 1 & 0.7 & Uncultured Pseudomonadaceae & EU721823 & 96 \\
\hline 1 & 0.7 & Citrobacter freundii $^{1}$ & GQ983053 & 98 \\
\hline 16 & 10.5 & Enterobacteriaceae $^{1}$ & EU272859 & 99 \\
\hline 1 & 0.7 & Enterobacter $\mathrm{sp}^{1}$ & FN433019 & 88 \\
\hline 2 & 1.3 & Pantoea ananatis ${ }^{1}$ & AY579212 & 98 \\
\hline 3 & 2.0 & Enterobacter cloacae ${ }^{1}$ & AB244469 & 99 \\
\hline 2 & 1.3 & Klebsiella oxytoca ${ }^{1}$ & GU003834 & 99 \\
\hline 5 & 3.3 & Enterobacter $\mathrm{sp}^{1}$ & GQ360072 & 92 \\
\hline 2 & 1.3 & Enterobacteriaceae & DQ068793 & 99 \\
\hline 2 & 1.3 & Enterobacter $\mathrm{sp}^{1}$ & GQ062425 & 99 \\
\hline 1 & 0.7 & Pseudomonas $\mathrm{sp}^{1}$ & EF581815 & 90 \\
\hline 3 & 2.0 & Pseudomonas $\mathrm{sp}^{1}$ & EF179816 & 99 \\
\hline
\end{tabular}

The phylogenetic relationships between the main bacterial taxa identified from $16 \mathrm{~S}$ rRNA gene sequences from sugarcane endophytes and sequences retrieved from GenBank are shown in Figure 2. In agreement with previous analyses, most of the 16S rRNA gene sequences of sugarcane endophytes (identified in the figure with a black triangle and with the initial letters CA) were clustered in the families Enterobacteriaceae and Pseudomonadaceae. Among the family Enterobacteriaceae, the majority of the sequences grouped with Enterobacter or Pantoea sp. 


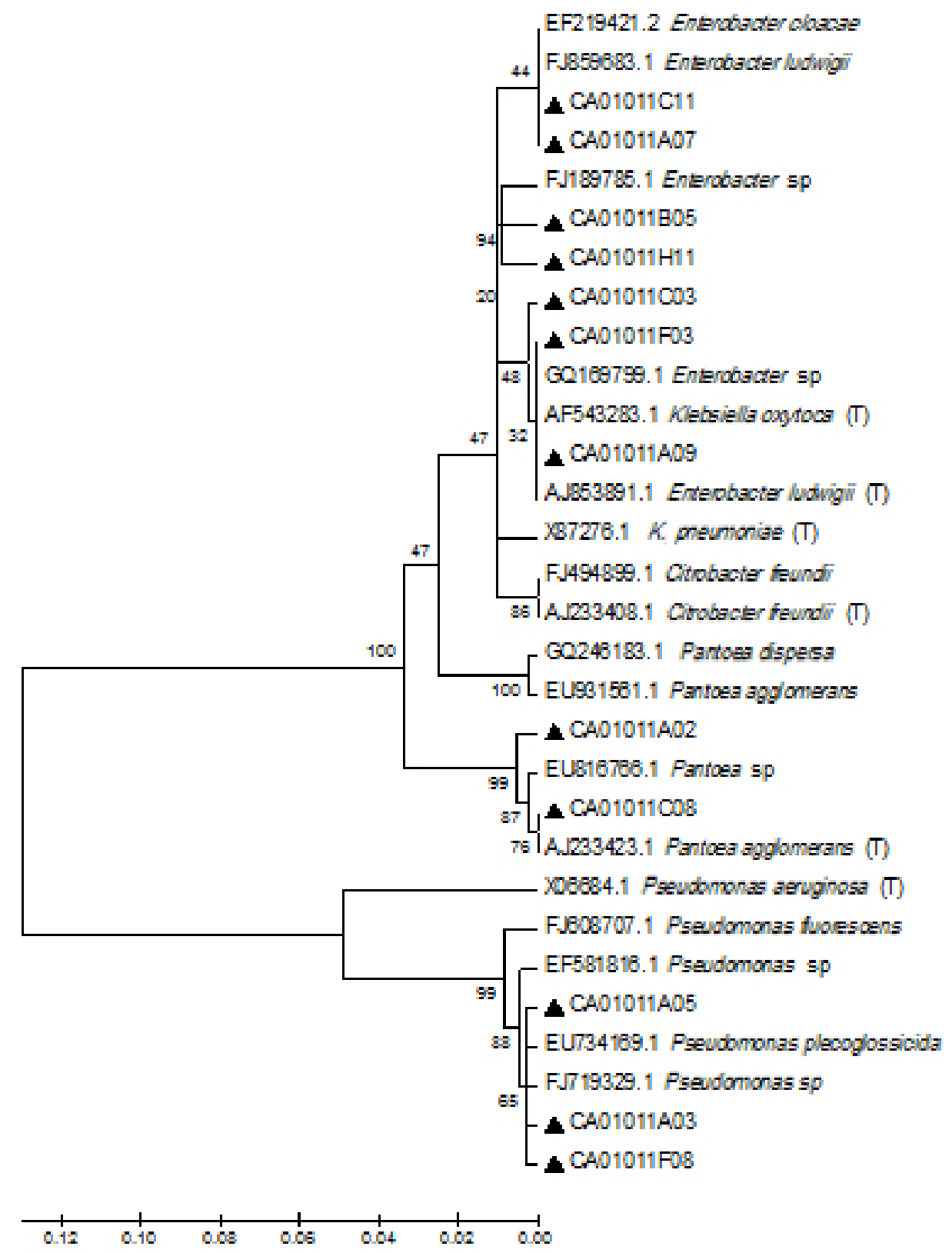

Figure 2. Phylogenetic affiliation of the endophytic bacteria from sugarcane. Unrooted phylogenetic tree positioning the sugarcane endophytes in the families Enterobacteriaceae and Pseudomonadaceae. Sequences of the 16S rRNA gene from sugarcane endophytes are indicated by a black triangle. The sequences with a $(T)$ in the end are from type strains. The tree was constructed using the neighbor-joining method with Jukes and Cantor distance parameters from aligned sequences. The values in the nodes are percentage for 1000 bootstrap replicates. The scale bar means number of nucleotide substitution per site. 


\section{DISCUSSION}

Previously, we isolated endophytes of sugarcane stems grown in Paraná State on potato medium and identified the bacteria by $16 \mathrm{~S}$ rRNA sequencing and biochemical tests. The results revealed a prevalence of Enterobacteriaceae, with Enterobacter sp being the most frequently isolated bacterium (Magnani et al., 2010). In this study, we used direct amplification of the 16S rRNA gene from total DNA extracted from sugarcane stems, cloning and sequencing to identify the bacterial endophytes. Analyses of the sequences showed a dominance of Proteobacteria associated with healthy sugarcane stems. Although the number of phyla and families of Bacteria identified was relatively low, the results are consistent with other studies of endophytic diversity (Roesch et al., 2008; Prakamhang, 2009; Magnani et al., 2010; Taulé et al., 2012), which found that Proteobacteria is the group of bacteria most frequently associated with plants. Fischer et al. (2011) also found a high number of Proteobacteria with 80-100\% of the sequences from 16S rRNA libraries belonging to Alphaproteobacteria of the families Acetobacteraceae, Bradyrhizobiaceae, and Rhodobacteraceae.

Apart from Proteobacteria, Firmicutes, Actinobacteria, and Bacteroidetes have also often been found as endophytes of graminaceous plants in cultivation-dependent studies but with a low prevalence (Rosenblueth and Martinez-Romero, 2006). In our study, the sugarcane endophytes were distributed in the families Pseudomonadaceae and Enterobacteriaceae. The sequences related to the Pseudomonadaceae made up the largest fraction of the clone library ( $50 \%$ of the clones). When compared with GenBank, several 16S rRNA gene sequences were closely related to sequences obtained from bacteria that live in plants or in soil. Moreover, several clones had sequences of high similarity to sequences from Enterobacteria and Pseudomonadaceae with potential use in agriculture, such as a chlorobenzene-degrading bacterium, a copper-resistant strain from soil, and phosphate-solubilizing bacteria from tea plant rhizosphere (data not shown).

In contrast to our results, several studies found endophytic diazotrophic organisms such as Herbaspirillum sp, Azospirillum sp, and G. diazotrophicus in sugarcane (Reis Junior et al., 2000). These bacteria, frequently isolated in high numbers associated with sugarcane roots, stems, and leaves, and considered candidates for nitrogen fixation (James, 2000), were not found in our sample. The lack of such sequences was not due to primer bias, since analysis of the primers used in the PCR amplification revealed a 100\% match with target $16 \mathrm{~S}$ rRNA gene sequences from these diazotrophic bacteria (data not shown). Moreover, other studies also failed to identify them. For example, the nifH-transcripts of $H$. seropedicae, $H$. rubrisubalbicans, and $A$. amazonense were also not detected in long-term field experiments of inoculated sugarcane (Fischer et al., 2011). In addition, a low diversity was observed among the active diazotrophic bacterial community in sugarcane roots from Africa and America, with dominant phylotypes related to Rhizobium rosettiformans, Sulfurospirillum multivorans, or Bradyrhizobium elkanii (Burbano et al., 2011). Suman et al. (2001) showed that the number of diazotrophic endophytes isolated in LGI semi-solid medium, per gram of fresh roots of several sugarcane cultivars, ranged from 0.02 to $3.86 \%$ of the total endophytic population. Also using cultivation-dependent techniques, Rennie et al. (1982) found mainly isolates from the family Enterobacteriaceae in sugarcane, and Taulé et al. (2012) found a high prevalence of Gammaproteobacteria, including Pseudomonas sp, Pantoea sp, and Enterobacter sp, in the inner tissues of sugarcane stems from Uruguay. It is interesting to note that members of 
the genera found in the stems of sugarcane RB-72454, such as Enterobacter, Klebsiella, and Pseudomonas, have been shown to fix nitrogen and promote plant growth (Rosenblueth and Martinez-Romero, 2006; Taulé et al., 2012).

Cultivation-independent methods are advantageous because they do not need the isolation of the organisms, allowing the assessment of a larger portion of microorganisms. On the other hand, in culture-dependent methods the growth conditions select mainly fast-growing organisms, well adapted to the medium conditions. Although bias in PCR amplification and the limitation in the number of sequences do not allow for a complete view of bacterial diversity, it is largely accepted that culture-independent approach can reveal the dominant organisms in an environmental sample (Ward et al., 1998).

Using a culture-independent method, Sun et al. (2008) found a larger diversity of endophytes in rice roots. A total of 52 OTUs were defined on the basis of ARDRA and 16S rRNA gene sequencing of selected clones from each OTU, which revealed bacteria belonging to Proteobacteria, Cytophaga/Flexibacter/Bacteroides (CFB) group, low G+C Gram-positive bacteria, Deinococcus-Thermus, and Acidobacteria. The dominant class was Betaproteobacteria (27\% of the total clones), but the most dominant genus was Stenotrophomonas of Gammaproteobacteria (Sun et al., 2008). A taxonomic analysis of the nifH libraries of maize stems showed the presence of the Alpha-, Beta-, and Gammaproteobacteria classes, with no subdivision being dominant (Roesch et al., 2008). Our results suggest a lower diversity at higher taxonomic ranks of endophytes in mature sugarcane stems. This relatively lower diversity may be due in part to the tissue used (stem), the age of the plant (10 months), and geographic localization of the plantation (southern Brazil). In addition, a cultivar-dependent effect on the selection of endophytic bacteria cannot be excluded.

The results suggest that the endophytic communities in sugarcane stems, and perhaps in other Poaceae, are large and dominated by Proteobacteria. Also, it is likely that such populations can be manipulated by means of selective inoculation to favor plant productivity.

\section{ACKNOWLEDGMENTS}

Research supported by CNPq-Instituto do Milênio, INCT da Fixação Biológica de Nitrogênio, PRONEX-Fundação Araucária, and CAPES. We thank Roseli Prado and Julieta Pie for technical support.

\section{REFERENCES}

Altschul SF, Madden TL, Schaffer AA, Zhang J, et al. (1997). Gapped BLAST and PSI-BLAST: a new generation of protein database search programs. Nucleic Acids Res. 25: 3389-3402.

Araujo WL, Marcon J, Maccheroni W, Jr., Van Elsas JD, et al. (2002). Diversity of endophytic bacterial populations and their interaction with Xylella fastidiosa in citrus plants. Appl. Environ. Microbiol. 68: 4906-4914.

Baldani JI, Baldani VLD, Seldin L and Döbereiner J (1986). Characterization of Herbaspirillum seropedicae gen. nov., sp. nov., a root-associated nitrogen fixing bacterium. Int. J. Syst. Bacteriol. 36: 86-93.

Burbano CS, Liu Y, Rosner KL, Reis VM, et al. (2011). Predominant nifH transcript phylotypes related to Rhizobium rosettiformans in field-grown sugarcane plants and in Norway spruce. Environ. Microbiol. Rep. 3: 383-389.

Cavalcante VA and Döbereiner J (1988). A new acid-tolerant nitrogen-fixing bacterium associated with sugarcane. Plant Soil 108: 23-21.

Cole JR, Wang Q, Cardenas E, Fish J, et al. (2009). The Ribosomal Database Project: improved alignments and new tools for rRNA analysis. Nucleic Acids Res. 37: D141-D145.

Ewing B, Hillier L, Wendl MC and Green P (1998). Base-calling of automated sequencer traces using phred. I. Accuracy 
assessment. Genome Res. 8: 175-185.

Fischer D, Pfitzner B, Schmid M and Simões-Araujo JL (2011). Molecular characterization of the diazotrophic bacterial community in uninoculated and inoculated field-grown sugarcane (Saccharum sp.). Plant Soil 356: 83-99.

Germida JJ, Siciliano SD, Freitas R and Seib AM (1998). Diversity of root-associated bacteria associated with field-grown canola (Brassica napus L.) and wheat (Tritricum aestivum L.). FEMS Microbiol. Ecol. 26: 43-50.

Hall TA (1999). BioEdit: a user-friendly biological sequence alignment editor and analysis program for Windows 95/98/ NT. Nucleic Acids Symposium Series 41: 95-98.

Hallmann J, Quadt-Hallmann A, Mahaffee AWF and Kloepper JW (1997). Bacterial endophytes in agricultural crops. Can. J. Microbiol. 43: 895-914.

James EK (2000). Nitrogen fixation in endophytic and associative symbiosis. Field Crops Res. 65: 197-209.

Kuklinsky-Sobral J, Araujo WL, Mendes R, Geraldi IO, et al. (2004). Isolation and characterization of soybean-associated bacteria and their potential for plant growth promotion. Environ. Microbiol. 6: 1244-1251.

Kumar S, Nei M, Dudley J and Tamura K (2008). MEGA: a biologist-centric software for evolutionary analysis of DNA and protein sequences. Brief. Bioinform. 9: 299-306.

Lane DJ (1991). 16S/23S rRNA Sequencing. In: Nucleic acid Techniques in Bacterial Systematics (Stackebrandt E and Goodfellow M, eds.). John Wiley and Sons, New York, 115-175.

Magnani GS, Didonet CM, Cruz LM, Picheth CF, et al. (2010). Diversity of endophytic bacteria in Brazilian sugarcane. Genet. Mol. Res. 9: 250-258.

Oliveira ALM, Urquiga S, Döbereiner J and Baldani JI (2002). The effect of inoculating endophytic N2 fixing bacteria on micropropagated sugarcane plants. Plant Soil 242: 205-215.

Pachiadaki MG, Lykousis V, Stefanou EG and Kormas KA (2010). Prokaryotic community structure and diversity in the sediments of an active submarine mud volcano (Kazan mud volcano, East Mediterranean Sea). FEMS Microbiol. Ecol. 72: 429-444.

Pedrosa FO and Yates MG (1984). Regulation of nitrogen fixation (nif) genes of Azospirillum brasilense by nifA and ntrC $(\mathrm{g} \ln G)$ type genes. FEMS Microbiol. Lett. 55: 95-101.

Perrig D, Boiero ML, Masciarelli OA, Penna C, et al. (2007). Plant-growth-promoting compounds produced by two agronomically important strains of Azospirillum brasilense, and implications for inoculant formulation. Appl. Microbiol. Biotechnol. 75: 1143-1150.

Prakamhang JK, Minamisawa K, Teamtaisong N and Boonkerd N (2009). The communities of endophytic diazotrophic bacteria in cultivated rice (Oryza sativa L.). Appl. Soil Ecol. 42: 141-159.

Reis Junior FB, Silva LG, Reis VM and Döbereiner J (2000). Ocorrência de bactérias diazotróficas em diferentes genótipos de cana-de-açúcar. Pesq. Agropec. Bras. 35: 985-994.

Rennie RJ, Freitas JR, Ruschel AP and Vose PB (1982). Isolation and identification of $\mathrm{N}_{2}$-fixing bacteria associated with sugar cane (Saccharum sp.). Can. J. Microbiol. 28: 462-467.

Roesch LFW, Camargo FAO, Bento FM and Triplett EW (2008). Biodiversity of diazotrophic bacteria within the soil, root and stem of field-grown maize. Plant Soil 302: 91-104.

Rosenblueth M and Martinez-Romero E (2006). Bacterial endophytes and their interactions with hosts. Mol. Plant Microbe Interact. 19: 827-837.

Rout ME and Chrzanowski TH (2009). Endophytic diazotrophs: The latest weapon of an exotic invasive grass. Plant Soil 315: 163-172.

Schloss PD and Handelsman J (2005). Introducing DOTUR, a computer program for defining operational taxonomic units and estimating species richness. Appl. Environ. Microbiol. 71: 1501-1506.

Soares-Ramos J, Ramos HJO, Cruz LM and Chubatsu LS (2003). Comparative molecular analysis of Herbaspirillum strains by RAPD, RFLP, and 16S rDNA sequencing. Genet. Mol. Biol. 26: 537-543.

Suman A, Shasany AK, Singh M and Shahi HN (2001). Molecular assessment of diversity among endophytic diazotrophs isolated from subtropical Indian sugarcane. World J. Microbiol. Biotechol. 17: 39-45.

Sun L, Qiu F, Zhang X, Dai X, et al. (2008). Endophytic bacterial diversity in rice (Oryza sativa L.) roots estimated by $16 \mathrm{~S}$ rDNA sequence analysis. Microb. Ecol. 55: 415-424.

Taulé C, Mareque C, Barlocco C and Hackembruch F (2012). The contribution of nitrogen fixation to sugarcane (Saccharum officinarum L.), and the identification and characterization of part of the associated diazotrophic bacterial community. Plant Soil 356: 35-49.

Terakado-Tonooka J, Ohwaki Y, Yamakoura H and Tanaka F (2008). Expressed nifH genes of endophytic bacteria detected in field-grown sweet potatoes (Ipamoeba batatas L.). Microbes Environ. 23: 89-93.

Thompson JD, Higgins DG and Gibson TJ (1994). CLUSTAL W: improving the sensitivity of progressive multiple sequence alignment through sequence weighting, position-specific gap penalties and weight matrix choice. Nucleic Acids Res. 22: 4673-4680. 
Tian X, Cao L, Tan H, Han W, et al. (2007). Diversity of cultivated and uncultivated actinobacterial endophytes in the stems and roots of rice. Microb. Ecol. 53: 700-707.

Ward DM, Ferris MJ, Nold SC and Bateson MM (1998). A natural view of microbial biodiversity within hot spring cyanobacterial mat communities. Microbiol. Mol. Biol. Ver. 62: 1353-1370. 